Canadian Journal of Civil Engineering

Canadian

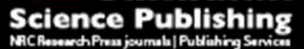
Revue canadienne de génie civil

\title{
Pilot production of steel slag masonry blocks
}

\begin{tabular}{|r|l|}
\hline Journal: & Canadian Journal of Civil Engineering \\
\hline Manuscript ID & cjce-2017-0603.R1 \\
\hline Manuscript Type: & Article \\
\hline Complete List of Authors: & $\begin{array}{l}\text { Mahoutian, Mehrdad; McGill University, Civil Engineering } \\
\text { Chaallal, Omar; Université du Quebec/École de technologie supérieure, } \\
\text { Shao, Yixin; Dept. of Civil Engineering and Applied Mechanic, }\end{array}$ \\
\hline $\begin{array}{r}\text { Is the invited manuscript for } \\
\text { consideration in a Special } \\
\text { Issue? : }\end{array}$ & N/A \\
\hline Keyword: & $\begin{array}{l}\text { CO2 utilization, steel slag masonry blocks, carbonation, pilot study, } \\
\text { sustainability, construction < type of paper to review }\end{array}$ \\
\hline \multicolumn{2}{|l}{} \\
\hline
\end{tabular}

SCHOLARONE $^{\text {IM }}$

Manuscripts 


\title{
Pilot production of steel slag masonry blocks
}

\author{
Mehrdad Mahoutian $^{1}$, Omar Chaallal ${ }^{2}$, Yixin Shao ${ }^{1 *}$ \\ 1 Department of Civil Engineering and Applied Mechanics, McGill University, 817 Sherbrooke \\ Street, Montreal, Canada H3A 2K6 \\ 2 Department of Construction Engineering, École de technologie supérieure, 1100 Notre-Dame \\ St W, Montreal, Canada H3C 1K3 \\ *corresponding author Tel:+1-514-398-6674Ｅmail:yixin.shao@mcgill.ca
}

\begin{abstract}
Masonry blocks are usually made of Portland cement and cured by steam. This study explores the possibility of making masonry blocks using steel slag as binder and carbon dioxide as curing activator. By carbonation activation of steel slag blocks, carbon dioxide can be permanently sequestered in steel slag as calcium carbonates, leading to stronger and more durable construction blocks. In this paper, carbonated steel slag paste was first evaluated by thermogravimetry, derivative thermogravimetry, X-ray diffraction, carbon uptake, strength development and leaching tests. Based on the preliminary results, the full-size masonry blocks were fabricated using steel slag as the binder and granite as the aggregates. The physical properties and durability of full-size steel slag masonry blocks were then examined through their density, water absorption, moisture content, compressive strength and fire resistance. An economic analysis was performed and a carbon dioxide utilization capacity was estimated. This study demonstrates that production of steel slag masonry blocks by carbonation is an economically feasible way to utilize carbon dioxide.
\end{abstract}

Keywords: $\mathrm{CO}_{2}$ utilization, steel slag masonry blocks, carbonation, pilot study, sustainability, construction 


\section{Introduction}

Concrete masonry blocks are commonly used in construction for load-bearing walls and partition walls. Traditionally, the concrete masonry blocks are made of Portland cement as binder. In the United States and Canada, the annual production is estimated as 4.3 billion units for $200-\mathrm{mm}$ block equivalent (Freedonia 2010). The corresponding Portland cement consumption is about 8 Mt per year. The production of cement is an energy-intensive and carbon-emitting process. Therefore, it is imperative to find cement replacement in masonry block manufacturing to reduce the embodied energy and to develop a feasible way to utilize $\mathrm{CO}_{2}$ in production of value-added construction products.

Steel slag seems to be a promising alternative. Steel slag is the by-product of steel making process. Its annual production is about 130 million tonnes worldwide (Zomeren et al. 2011). It is mostly produced in Electrical Arc Furnace (EAF) and Basic Oxygen Furnace (BOF). Currently, the steelmaking by-products are mainly marketed as aggregates for construction often used in the asphalt pavement (Pasetto and Baldo 2012; Huang et al. 2007), the roadbed construction (Das et al. 2007) and the concrete pavement (Neitinger et al. 2011). The application of steel slag as raw materials in cement production and as fluxing agent has been also reported (Yi et al. 2012). Steel slag is not popular for concrete as supplementary cementitious material because it does not show hydraulic behavior. However, steel slag has shown the potential to replace cement as an alternative binder if carbonation activation is performed (Mahoutian and Shao 2016). Isoo et al. (2000) reported that a $1 \mathrm{~m}^{3}$ slag block reached a compressive strength of $18.4 \mathrm{MPa}$ after 12 days of carbonation for seaweed bed application. Stainless steel slag compacts exposed to carbon dioxide for one hour achieved a compressive strength of $9 \mathrm{MPa}$ and a carbon dioxide uptake of 
$18 \%$ (Johnson et al. 2003). Production of carbonate aggregate from steelmaking slag and carbon dioxide were also reported (Ghouleh et al. 2017; Teir et al. 2016). It was also found that carbonation activation, $\mathrm{CO}_{2}$ treatment, of steel slag to achieve early strength can be obtained by a carbon sequestration process (Mahoutian and Shao 2016; Pan et al. 2016). Replacement of cement with slag and utilization of carbon dioxide in production of construction products will lead to a reduction in carbon dioxide emission and a feasible way to utilize $\mathrm{CO}_{2}$ in production of value-added constructing products. Meanwhile, the main challenge to fully implement the technology in the concrete masonry industry is the consistency of the steel slag. Steel factories make steel with various specifications resulting in production of steel slag with different chemical composition and structure. An intense quality control should be implemented to continuously provide proper steel slag to the concrete masonry manufactures.

This paper presents the results of a study on pilot tests carried out to demonstrate the potential of using carbon dioxide in making steel slag masonry blocks. The characteristic properties of activated steel slag paste was first examined. Full size steel slag masonry blocks, 400x200x200 $\mathrm{mm}$, were then mass produced using industry scale block machine. The mechanical and durability properties of the steel slag blocks were evaluated in terms of water absorption, density, compressive strength, moisture content, carbon dioxide content and fire resistance. This paper also investigated the carbon dioxide utilization capacity and the implementation of production of full size steel slag masonry blocks. The pilot test of steel slag masonry blocks production demonstrates an economic way of utilizing carbon dioxide.

\section{Materials and the process}




\subsection{Steel slag}

Steel slag used in this pilot study was collected from ArcelorMittal Dofasco Steel Mill in Ontario, Canada. This particular steel mill produces 0.5 million tonne of steel slag every year. Figure 1 shows the steel slag in slag yard at the plant. The chemical compositions of steel slag obtained by the X-ray fluorescence (XRF) spectrometry are shown in Table 1. The main oxides are calcium oxide, iron oxide and silica oxide.

\subsection{Steel slag grinding}

Steel slag needs to be fine enough in order to be able to react with carbon dioxide. Previous studies demonstrate that slag particle size and its surface area played the most important role on the reaction, smaller grain sizes proving more reactive with $\mathrm{CO}_{2}$ (Baciocchi et al. 2009). Asreceived slag had a maximum aggregate size of $10 \mathrm{~mm}$ and was pulverized in an industrial ballmill grinder. The sieve analysis of the ground slag suggests D50 and D80 be used. D50 and D80 represent the size of grain where 50 and 80 percent of grains are smaller than 19 and 60 microns, respectively. Figure 2 shows the particle size analysis results. Steel slag is harder compared to the cement clinker and therefore it is expected to consume more energy for the same fineness as cement particles. The energy consumption for slag grinding to the finesses of $\mathrm{D} 50=19$ microns was calculated as $36.7 \mathrm{kWh}$ per metric tonne. This consumed energy was determined considering that a $2.2 \mathrm{~kW}$ pulverizer operated for 60 seconds to grind $1 \mathrm{~kg}$ of steel slag. As reference, grinding of one tonne of cement clinker consumes an energy of $23 \mathrm{kWh} / \mathrm{t}$ (Madlool et al. 2011).

\subsection{Carbonation - activated steel slag paste}

Prior to making full-size steel slag masonry block, the reactivity of steel slag with carbon dioxide was determined. The details can be found in Mahoutian et al. (2015). Rectangular slag slab specimens were prepared by using 270 grams slag and 22 grams water for one specimen. The slag was mixed with water at water to slag ratio of 0.1 for 1 minute in a bowl mixer. The mix was then poured into a $127 \times 76 \mathrm{~mm}$ mould and pressed at $12.5 \mathrm{MPa}$ to form a uniform 
rectangular slab of $12 \mathrm{~mm}$ thickness. Immediately after slag slabs were formed, they were placed in a pressure chamber for carbonation. $\mathrm{A} \mathrm{CO}_{2}$ gas with a purity of $99.5 \%$ was used at $0.15 \mathrm{MPa}$ gas pressure for carbonation of the steel slag. The carbonation set up for the steel slag specimens is shown in Figure 3. The carbonation was carried out for either 2 or 24 hours to examine the effect of reaction time. The chamber is placed on a digital balance to record the mass curve that represents the carbon dioxide uptake during the carbonation reaction.

\subsection{Steel slag masonry block}

The mixture proportion for the steel slag masonry blocks is shown in Table 2. The water to slag ratio and slag to aggregate ratio were 0.20 and 0.58 , respectively. In a mobile industry concrete mixer, granite aggregate was first dry mixed with steel slag powder for two minutes and then mixed with water for another 3 minutes.

A commercial block machine shown in Figure 4 was used to make masonry block. It has the capacity of making 800 standard size blocks (400x200x200 mm) every day.

Fresh mixture was cast into the block maker molds with a shovel. The block maker machine compacted and vibrated the fresh concrete to form 400x200x200 mm blocks. In each batch, about $45 \mathrm{~kg}$ of mixture was prepared to make two full-size steel slag masonry blocks. The formed blocks were preconditioned in air by fans for four hours and then placed into a pressure chamber. Right after blocks formation, the saturation degree may be the same through the thickness. Meanwhile, after the drying step, surface is less saturated to allow more gas penetration to improve the carbon storage capacity. Figure 5 shows the carbonation set up for steel slag masonry blocks.

A $\mathrm{CO}_{2}$ gas with a purity of $99.5 \%$ was used for carbonation of the blocks. The $\mathrm{CO}_{2}$ gas was injected into the chamber to a pressure of $0.4 \mathrm{MPa}$. A regulator was used to maintain a constant pressure and ensure that the carbon dioxide taken by the blocks was continually replenished. Higher $\mathrm{CO}_{2}$ pressure was utilized for production of steel slag masonry blocks compared to steel slag paste in order to increase the carbon uptake and strength development. The carbonation was carried out for 24 hours. A parametric study could be performed to determine the optimum 
carbonation period. However, as a higher $\mathrm{CO}_{2}$ uptake was one of the targets of this study, a $24 \mathrm{~h}$ carbonation was executed in order to achieve a high carbon uptake.

After 24-hour carbonation curing, the steel slag masonry blocks were taken out of the chamber and were prepared for the mechanical and durability tests. In a period of 50 days, eighty blocks were produced with the described procedure. A sample of carbonation activated steel slag masonry block is shown in Figure 6. The typical block unit weighs $20.7 \mathrm{~kg}$ and contains $7.1 \mathrm{~kg}$ of steel slag.

\subsection{Property tests of steel slag paste}

Two methods were used to quantify $\mathrm{CO}_{2}$ uptake of the carbonated steel slag paste samples: the mass-gain method and the mass-curve method. The mass-gain method estimates the $\mathrm{CO}_{2}$ uptake in slag by comparing the mass of slag compacts before and after carbonation (Eq. 1). Carbonation is an exothermic reaction and, thus, accelerates water evaporation. The condensed water was collected by absorbent paper and added to the final mass.

$\mathrm{CO}_{2}$ uptake $(\%)=\frac{\text { Finalmass }+ \text { Massof } \text { waterloss }- \text { Initialmass }}{\text { Massof dryslag }} \times 100$

Mass-curve method determines $\mathrm{CO}_{2}$ uptake by recording the mass increase of the entire carbonation system. After the balance was set to zero, the gas was injected into the chamber at $0.15 \mathrm{MPa}$ and the mass increase due to carbon uptake of slag was recorded until the end of the process. The carbonation reaction continued for 2 or 24 hours at which time $\mathrm{CO}_{2}$ was released and the mass of the closed-loop system, $M$, was measured. The system was then calibrated by repeating the tests using $\mathrm{CO}_{2}$-nonreactive extruded polystyrene foam of the same volume to obtain the mass of the same system, $m$, which represented the residue carbon dioxide in the chamber. The difference between $M$ and $m$ is an estimate of the $\mathrm{CO}_{2}$ uptake by slag compacts (Eq. 2). 


$$
\mathrm{CO}_{2} \text { uptake }(\%)=\frac{M-m}{\text { Massof dryslag }} \times 100
$$

Compressive strength of carbonated steel slag paste was determined immediately after carbonation and 35 days after the carbonation curing process. The carbonated steel slag paste samples were sealed in plastic bag during their subsequent hydration.

X-ray diffraction (XRD) analysis of the steel slag and carbonated steel slag was carried out to identify the mineralogical phases. The XRD analyses were performed with a Bruker D8 Diffractometer $\left(\mathrm{Cu} \mathrm{K} \alpha\right.$ radiation, scan interval $\left.15-80^{\circ} 2 \theta, 0.02^{\circ}\right)$.

Thermogravimetry analysis of steel slag and carbonated steel slag was conducted with a NETZSCH, TG 449F3 Jupiter thermal analyzer. The test was performed with a resolution of $0.01 \mathrm{mg}$ at a heating rate of $10^{\circ} \mathrm{C} / \mathrm{min}$ up to $1,000^{\circ} \mathrm{C}$ under an argon atmosphere at a gas flow rate of $50 \mathrm{ml} / \mathrm{min}$ to determine the nature and quantity of carbonation products. The mass loss between $105-550{ }^{\circ} \mathrm{C}$ and $550-1000{ }^{\circ} \mathrm{C}$ are used to quantify the calcium-based hydration products and calcium carbonate $\left(\mathrm{CaCO}_{3}\right)$ content, respectively. Given the molecular weight of the constituent element, the $\mathrm{CaCO}_{3}$ content was calculated using the $\mathrm{CO}_{2}$ loss from the TG tests.

Leaching behavior of carbonated steel slag paste sample was also studied. The Toxicity Characteristic Leaching Procedure (TCLP) test was conducted on the powder of carbonated slag paste to determine the mobility of metals from slag under acidic conditions. The leaching of arsenic, barium, cadmium, chromium, lead, selenium, silver, mercury, zinc, vanadium, molybdenum and nickel was evaluated.

\subsection{Performance of steel slag masonry block by carbonation}

The carbon dioxide uptake of full-size steel slag masonry blocks was measured with the massgain method (Eq 1) as explained earlier. The density, water absorption and compressive strength of the steel slag masonry blocks were determined in accordance with ASTM C140 (2014) and reported as the average of 3 sample tests. The top surface of blocks was flattened with the sulphur compound cap before conducting the compressive strength test. 
Fire resistance test on steel slag masonry blocks was executed in accordance with ASTM E119 (2016). A concrete masonry wall was built inside the opening of a steel frame. The steel frame size and opening size were $1960 \times 2490 \mathrm{~mm}$ and 1320x1575mm, respectively. The wall was constructed in 3 columns and 7 rows using 21 blocks. To fill the gaps between the top layer of the wall and steel frame, few blocks were cut and placed into the gaps. Before constructing the wall, blocks were sprayed with water to provide a better bond with the mortar. Ten thermocouples were installed on the other side of the wall which was not exposed to fire (unexposed face). The thermocouples locations were chosen in a way to be able to track the temperature change of both mortar and blocks. The locations of the installed thermocouples are shown in Figure 7. Three furnaces provided high-temperature heating. The furnace temperature was controlled to follow the standard time-temperature curve suggested by ASTM E119 (2016). Three furnace thermocouples were placed $152 \mathrm{~mm}$ away from exposed face of the wall. The temperature of furnace and unexposed face of the wall were continuously recorded until the test came to its end. At the end of the fire test, the wall was visually inspected. The wall was then exposed to the steam hose for 34 seconds.

\section{Results and discussion}

\subsection{Steel slag paste}

\subsubsection{Carbon uptake, strength, microstructure and morphology}

The mass curves due to carbon uptake are shown in Figure 8. The curves suggest that carbon dioxide uptake was faster during the first two hours and continued at a reduced reaction rate afterwards. Theoretically, the $2 \mathrm{~h}$ and $24 \mathrm{~h}$ carbonation curves should overlap in the first 2 hours. But due to the consistency issue there is a small difference between the two curves. The $\mathrm{CO}_{2}$ uptake of $3 \%$ and $3.4 \%$ was calculated after 2 hours.

The quantified results of carbon dioxide uptake of steel slag paste are summarized in Table 3. The $\mathrm{CO}_{2}$ uptake measured by the mass gain method and mass curve method for the steel slag paste samples was in the same order of magnitude. It was noted that an increase in carbonation time from 2 hours to 24 hours resulted in a 34\% increase in the $\mathrm{CO}_{2}$ uptake. 
The results of compressive strength test are presented in Table 4. The compressive strength of carbonated steel slag paste after 24 hours carbonation was about twice the strength of slag subjected to only 2 hours carbonation, despite the increase in $\mathrm{CO}_{2}$ uptake between 2 and 24 hours of carbonation was only about 34\%. The steel slag displayed latent hydraulic properties. After 35 days subsequent hydration, the steel slag paste gained an additional $10 \mathrm{MPa}$ strength.

Figure 9 presents the XRD patterns of as-received and carbonated steel slag. Steel slag mainly consists of calcium silicate phases, wustite, gehlenite and merwinite. The presence of calcium carbonate and the reduction of calcium silicate phases $\left(\mathrm{C}_{2} \mathrm{~S}\right.$ and $\left.\mathrm{C}_{3} \mathrm{~S}\right)$ in the XRD pattern of carbonated steel slag were indicative of the carbonation reaction. Calcium hydroxide $(\mathrm{CH})$ was not detected after 24 hours of carbonation.

Figure 10 shows the TG/DTG curves for the as-received and the carbonated steel slag paste. Table 5 summarizes the water loss and $\mathrm{CO}_{2}$ loss from calcium-based hydration products and calcium carbonate, respectively. The calcium carbonate contents of as-received and carbonated steel slag are also reported in Table 5. The calcium carbonate content of steel slag raised from $3.8 \%$ to $16.2 \%$ suggesting the formation of calcium carbonate due to the carbonation reaction. The corresponding $\mathrm{CO}_{2}$ uptake by carbonation of steel slag paste was about $5.3 \%$, which was comparable to the results by mass gain and mass curve methods (Table 3 ). It suggests that the mass gain and mass curve methods presented the $\mathrm{CO}_{2}$ uptake values where $\mathrm{CO}_{2}$ was chemically bonded. The formation of calcium-based hydration products was noticed after carbonation. The TG/DTG results reveal that the water loss in the calcium-base hydration products increased from $2.6 \%$ to $5.6 \%$ due to carbonation activation. This observation indicates the formation of calciumbased hydration products as a result of the carbonation curing. The generation of calcium-based hydration products suggests that carbonation curing of steel slag not only produces calcium carbonates but also produces hydrates. It is believed that the combination of calcium carbonate crystals with the calcium-based hydration products contributes to the strength gain. 


\subsubsection{Leaching behavior}

The results of the leaching test for the carbonated steel slag and the allowable limits are presented in Table 6. No trace of leached poisonous and toxic elements like lead or mercury was reported for the carbonated steel slag. The detected non-toxic elements such as silver and zinc show lower values with respect to the allowable thresholds according to EPA (2009) suggesting that carbonated steel slag is non-hazardous material owing to its limited release of trace contaminants. It is worth noting that the reported results represent elements released from the steel slag paste sample not concrete. Steel slag masonry block contains both paste and aggregate and therefore, the leaching elements of the blocks are expected to be even lower compared to the paste. The leaching test on the fresh (i.e. not carbonated) steel slag was not conducted in this study; however, the leaching behaviour of steel slag was well reported in the literature. Table 6 also presents the leaching potential of steel slag publicised in Proctor et al. (2000) to compare it with leaching potential of carbonated steel slag.

\subsection{Steel slag masonry block}

\subsubsection{Carbon uptake, water absorption and moisture content}

The process parameter and the carbon uptake value are summarized in Table 7. The carbon dioxide uptake of steel slag masonry block reached $10.7 \%$ based on mass of steel slag paste. This number was higher than 4.7\% (Table 3) and 5.3\% (Table 5) from steel slag paste tests. It was partially due to the higher gas pressure $(0.4 \mathrm{MPa})$ used in carbonation of masonry blocks and partially due to more porous nature of the blocks because of the use of aggregates. The authors believe that this difference between the $\mathrm{CO}_{2}$ uptake values cannot be due to carbonation of CSH as there is no enough time for generation of CSH in the blocks as the blocks get carbonated few hours after formation of blocks. Considering the mass ratio of slag to the block (Table 2), one typical slag block containing $7.1 \mathrm{~kg}$ of slag binder can sequester $0.76 \mathrm{~kg}$ of carbon dioxide in the form of calcium carbonates.

The results of water absorption and moisture content of steel slag masonry blocks and cement masonry blocks as a reference are presented in Table 8. The water absorption of the steel slag masonry block was determined as $6.9 \%$. The water absorption for the steel slag masonry block 
was $25 \%$ higher compared to the cement masonry block. Despite the water absorption of steel slag masonry blocks was relatively higher compared to the commercial cement masonry block, the absorption value was within the limit set by ASTM for load-bearing concrete masonry units (ASTM C90 2014). The moisture content of steel slag masonry block was measured as $1.5 \%$ which was close to the moisture content of cement masonry blocks. The moisture content was calculated based on difference in mass of dry steel slag masonry block and its mass at room temperature.

\subsubsection{Compressive strength and density}

Table 9 shows the values of compressive strength and density for the steel slag masonry blocks. The compressive strength was calculated according to the net area. The average of compressive strength of the steel slag masonry block was determined as $23.1 \mathrm{MPa}$. The compressive strength of steel slag masonry block satisfied the minimum requirements for the load-bearing masonry units suggested by ASTM C90 (2014). The density of the steel slag masonry block was calculated as $2243 \mathrm{~kg} / \mathrm{m}^{3}$ that falls in the category of normal weight cement masonry blocks (density of $2100 \mathrm{~kg} / \mathrm{m}^{3}$ and higher) according to the standard (ASTM C90 2014).

\subsubsection{Fire resistance and hose steam test}

Figure 11 shows the temperature curves of fire tests on the fire side of masonry wall. The temperature of all three furnaces rapidly increased to $800^{\circ} \mathrm{C}$ in 20 minutes. After 20 minutes from the start, the temperature increase of the furnaces was slow and reached to $1020{ }^{\circ} \mathrm{C}$ after 139 minutes. On the order side of the wall, the heat transfer was monitored by thermocouples 15 and thermocouples 6-10, respectively (Figure 12) as fire performance of the wall. The temperature remained constant in first $20 \mathrm{~min}$ and started to increase afterwards. Thermocouples records suggest a temporarily stop in temperature increase at 60 minutes. The rise of temperature continued again after 80 minutes from the beginning of the test. Presence of air in the blocks holes delayed the heat transfer from the exposed side to the other side.

The fire test was conducted for two hours and nineteen minutes. The test was stopped as the average temperature on the unexposed side increased by $139{ }^{\circ} \mathrm{C}$ above its initial temperature 
(ASTM E119 2016). At the end of the fire test, no significant spalling or damage was observed. The exposed and unexposed side of the wall at the end of the fire test is shown in Figure 13. The wall was then removed from the furnace and exposed to a hose stream for 34 seconds to evaluate the wall structural integrity. The visual observation of the wall after the hose steam test showed that the wall remained in place and intact. There was no through-the-thickness damage generated by the high-pressure hose steam. It was concluded, based on fire tests, that the carbonated steel slag masonry wall could stand at least 2 hour fire and the fire resistance rating of the units is determined as 2 hours. According to the national building code of Canada (NBCC 2015), the minimum required equivalent thickness for fire resistance rating of 2 hours should be more than $113 \mathrm{~mm}$. Considering the solid ratio of the steel slag masonry block as $60 \%$, the equivalent thickness of the produced block is calculated as $120 \mathrm{~mm}$, which satisfies the minimum equivalent thickness required by the code.

\subsection{Carbon dioxide utilization capacity}

In United States and Canada, steel mills produce 14 million tonnes of steel slag every year. If all of the steel slags were available for the steel slag masonry block production, approximately two billion units of standard size $(400 \times 200 \times 200 \mathrm{~mm})$ steel slag masonry blocks would be produced. This represents more than $50 \%$ of masonry block market in these two countries. If each block can uptake $0.76 \mathrm{~kg} \mathrm{CO}_{2}$, production of two billion steel slag blocks results in an annual sequestration of 1.5 million tonnes of $\mathrm{CO}_{2}$. This amount of carbon dioxide utilization will reduce carbon emission from cement production by $2.1 \%$ assuming the cement production is $90 \mathrm{Mt}$ per year in these two countries and the carbon emission is $0.8 \mathrm{t} \mathrm{CO}_{2}$ per tone of cement. It should be noted that production of 2 billion commercial cement masonry blocks requires 3.6 million tonnes of cement, leading to an emission of 2.9 million tonnes of $\mathrm{CO}_{2}$ into atmosphere. The replacement of cement by steel slag will further reduce the carbon emission by $2.9 \mathrm{Mt}$ per year. Therefore, implementation of the carbon utilization through steel slag masonry block production in US and Canada will avoid carbon dioxide emission by 4.4 million tonnes into the atmosphere every year. It may be of interest to know if $\mathrm{CO}_{2}$ utilization in steel slag masonry block production is economically feasible. The cost comparison is conducted mainly between cement binder with 
steam curing and steel slag binder with carbon dioxide curing. As reference, cement costs \$100/t (USGS 2014) and energy consumption for steam curing varies from 30 to $76 \mathrm{kWh}$ for 1 cubic meter of concrete (Susanto et al. 2014); energy consumption of $71.7 \mathrm{kWh} / \mathrm{m}^{3}$ is chosen in the current study as suggested by Marceau et al. (2007). Given the electricity cost of $0.06 \$$ per $\mathrm{kWh}$, the steam curing cost for 100 cement blocks is calculated as $3.4 \$$. For a typical $200-\mathrm{mm}$ cement block weighing $18 \mathrm{~kg}$, the cement content is about $1.8 \mathrm{~kg}$. The cost of cement for each block is $\$ 0.18$. Considering the steam cost at $\$ 0.03 /$ unit, the cost for cement per block with steam is $\$ 0.21$. For steel slag block activated by carbon dioxide, single block contains $7.1 \mathrm{~kg}$ slag and can utilize $0.76 \mathrm{~kg} \mathrm{CO}_{2}$. The binder and curing costs of slag masonry block include:

(1) Cost of raw steel slag. Since steel slag is an industry waste, it is sold at $\$ 3 /$ t. Single block requires $7.1 \mathrm{~kg}$ of slag which costs $\$ 0.02$.

(2) Cost of grinding to D50 of 19 -micron particle size. It consumes $37 \mathrm{kWh} / \mathrm{t}$, leading to $\$ 0.02$ per block.

(3) Cost of $\mathrm{CO}_{2}$ gas. If $\mathrm{CO}_{2}$ gas can be sold at $\$ 50 / \mathrm{t}$, the gas cost per block is $\$ 0.04$. The total cost of carbonated slag binder will be $\$ 0.08$, one third of the price of the cement. To make the cost comparable to cement at $\$ 0.21$ /unit, the gas price can go as high as $\$ 220 /$ t. At current gas price of $\$ 100 / t$, the steel slag masonry block is still cost effective and economically competitive. The summary of the cost and utilization in the North America market is presented in Table 10. The carbon tax was not considered for the above estimations. Implementation of carbon tax even further makes the steel slag masonry block economically feasible. Either the cement manufacturers or precast concrete producers will be liable for the carbon tax. In Canada, the carbon tax is planned to raise to 50\$/tonne in 2022. Each mid-size concrete block maker produces 25,000 blocks per day. Utilization of 13,000 tonnes of cement in a mid-size concrete block plant is equivalent of emissions of 11,000 tonnes of carbon dioxide in the atmosphere. Considering the price of carbon tax at $50 \$ /$ tonne, a 550,000\$ debt/liability for the cement/concrete producer is obtained. This liability will be eliminated if the concrete block producers completely replace cement with steel slag to produce steel slag masonry block.

An existing concrete block plant requires a modification in order to be able to produce steel slag masonry blocks according to the described technology. The capital cost of this adjustment is 
estimated as $1.5 \mathrm{M} \$$. Considering the materials saving of $0.21-0.08=0.13 \$$ per unit, the initial investment for adjusting the existing concrete plant will be paid off after 2 years.

\section{Conclusions}

This paper presents a pilot study on a production of full size steel slag masonry blocks. Carbonation curing technique was used to activate the early strength and at the same time to store the carbon dioxide in calcium carbonates. The results of carbonated steel slag paste suggested that steel slag can serve as a binder for making building products. The results of steel slag masonry blocks demonstrated that steel slag masonry block exhibited equal or even better mechanical and durability properties compared to the commercial cement masonry block. The leaching properties and fire resistance performance of steel slag masonry blocks were found to be satisfactory. The production of steel slag masonry blocks can consume $1.5 \mathrm{Mt} \mathrm{CO}_{2}$ per year if all steel slag produced in US and Canada can be used to make masonry blocks. Moreover, the replacement of Portland cement by steel slag in masonry blocks will also reduce the carbon emission by 2.9 Mt per year. In addition to carbon utilization, the carbonation activated steel slag products reduces natural resource consumption and avoids landfills of industry wastes. Production of steel slag masonry blocks using carbon dioxide is an economically feasible way to utilize carbon dioxide to produce value-added products.

\section{Acknowledgments}

The support by Natural Science and Engineering Research Council (NSERC) of Canada through the Idea to Innovation Program is gratefully acknowledged. The authors are also thankful to Dofasco Arcelormittal for steel slag. 


\section{References}

ASTM C90. 2014. Standard specification for loadbearing concrete masonry units. ASTM International, PA, USA.

ASTM C140. 2014. Standard test methods for sampling and testing concrete masonry units and related units. ASTM International PA, USA.

ASTM E119. 2016. Standard Test Methods for Fire Tests of Building Construction and Materials, ASTM International PA, USA.

Baciocchi, R., Costa, G., Polettini, A., and Pomi, R. 2009. Influence of particle size on the carbonation of stainless steel slag for $\mathrm{CO}_{2}$ storage. Energy Procedia, 1:4859-4866.

Das, B., Prakash, S., Reddy, PSR., and Misra, V.N. 2007. An overview of utilization of slag and sludge from steel industries. Resources Conservation and Recycling, 501: 40-57.

EPA. 2009. Hazardous waste characterization, A user-friendly reference document, Resource Conservation and Recovery Act (RCRA), 30 pages.

Freedonia, G., 2010. Brick and Block. from http://www.freedoniagroup.com/DocumentDetails.aspx?DocumentId=506289.

Ghouleh, Z., Guthrie. I.L., and Shao, Y. 2017. Production of carbonate aggregates using steel slag and carbon dioxide for carbon-negative concrete. Journal of $\mathrm{CO}_{2}$ Utilization, 18:125-138.

Huang, Y., Bird, R., and Heidrich, O. 2007. A review of the use of recycled solid waste materials in asphalt pavement. Resources, Conservation and Recycling, 521:58-73.

Isoo T., Takahashi, T., Okamoto, N., and Fukuhara, M. 2000. Development of large steelmaking slag blocks using a new carbonation process. Advance Cement Research, 12:97-101.

Johnson, D.C., MacLeod, C., Carey, P., and Hills, C. 2003. Solidification of stainless steel slag by accelerated carbonation. Environmental Technology, 24:671-678.

Madlool, N.A., Saidur, R., Hossain, M.S., and Rahim, N.A. 2011. A critical review on energy use and savings in the cement industries. Renewable and Sustainable Energy Reviews, 15:20422060 .

Mahoutian, M., Shao, Y., Mucci, A., and Fournier, B. 2015. Carbonation and hydration behavior of EAF and BOF steel slag binders. Materials and Structure, 48: 3075-3085.

Mahoutian, M., and Shao, Y. 2016. Production of cement-free construction blocks from industry wastes. Journal of Cleaner Production, 137:1339-1346. 
Marceau, M., Nisbet, M., and VanGeem, M. 2007. Life cycle inventory of Portland cement concrete. Portland Cement Association. Research and Develop Information. PCA R\&D Serial No. 3011, 113 pp.

NBCC. 2015. National Building Code of Canada, National Research Council Canada, Volume 1, 708 pages.

Netinger, I., Bjegovic, D., and Vrhovac, G. 2011. Utilization of steel slag as aggregate in concrete. Materials and Structures, 44(9): 1565-1575.

Pan, S., Adhikari, R. Chen, YH., Li d, P., and Chiang, PC. 2016. Integrated and innovative steel slag utilization for iron reclamation, green material production and $\mathrm{CO}_{2}$ fixation via accelerated carbonation. Journal of Cleaner Production, 137:617-631.

Pasetto, M., and Baldo, N. 2012. Performance comparative analysis of stone mastic asphalts with electric arc furnace steel slag: a laboratory evaluation. Materials and Structures, 45(3): 411-424.

Proctor, DM., et al. 2000. Physical and chemical characteristics of blast Furnace, basic oxygen furnace, and electric arc furnace steel industry slags. Environmental and Science Technology, 34:1576-1582.

Susanto, A., Koleva, D.A., van Breugel, K. 2014. DC current-induced curing and ageing phenomena in cement-based materials. AMS '14 Proceedings of the Int. Conference on ageing of materials \& structures. Delft 26 - 28 May 2014, The Netherlands.

Teir, S., Kotiranta, T., Pakarinen, J., and Mattila, H.P. 2016. Case study for production of calcium carbonate from carbon dioxide in flue gases and steelmaking slag, Journal of $\mathrm{CO}_{2}$ Utilization, 14: 37-46.

USGS. 2014. https://minerals.usgs.gov/minerals/pubs/historical-statistics/. Accessed: January 09 2017]

Yi, H., Xu, G., Cheng, H., Wang, J., Wan, Y., and Chen, H. 2012. An overview of utilization of steel slag. Procedia Environmental Sciences, 16: $791-801$.

Zomeren, A., Laan, S., Kobesen, H., Huijgen, and W., Comasn, R. 2011. Changes in mineralogical and leaching properties of converter steel slag resulting from accelerated carbonation at low $\mathrm{CO}_{2}$ pressure. Waste Management, 31(11): 2236-2244. 
https://mc06.manuscriptcentral.com/cjce-pubs 


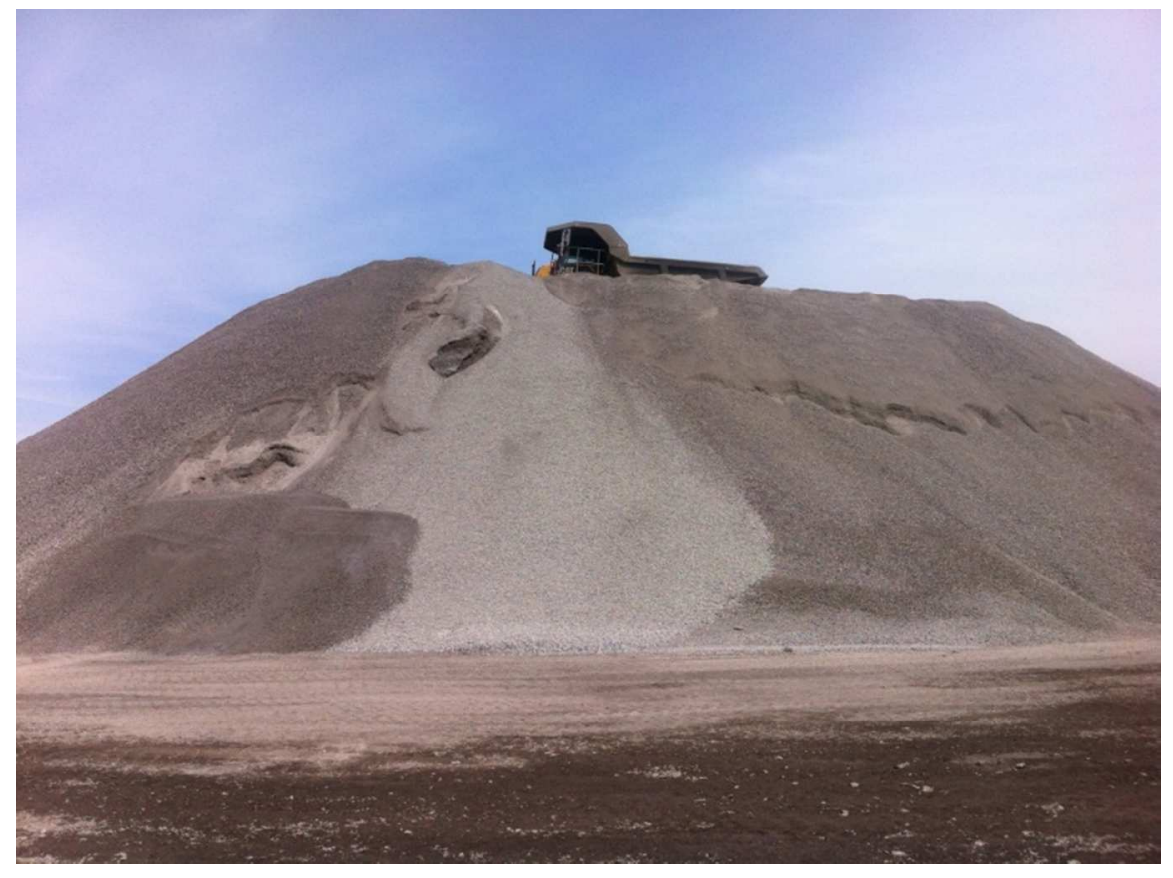

Fig. 1: Steel slag in steel plant 


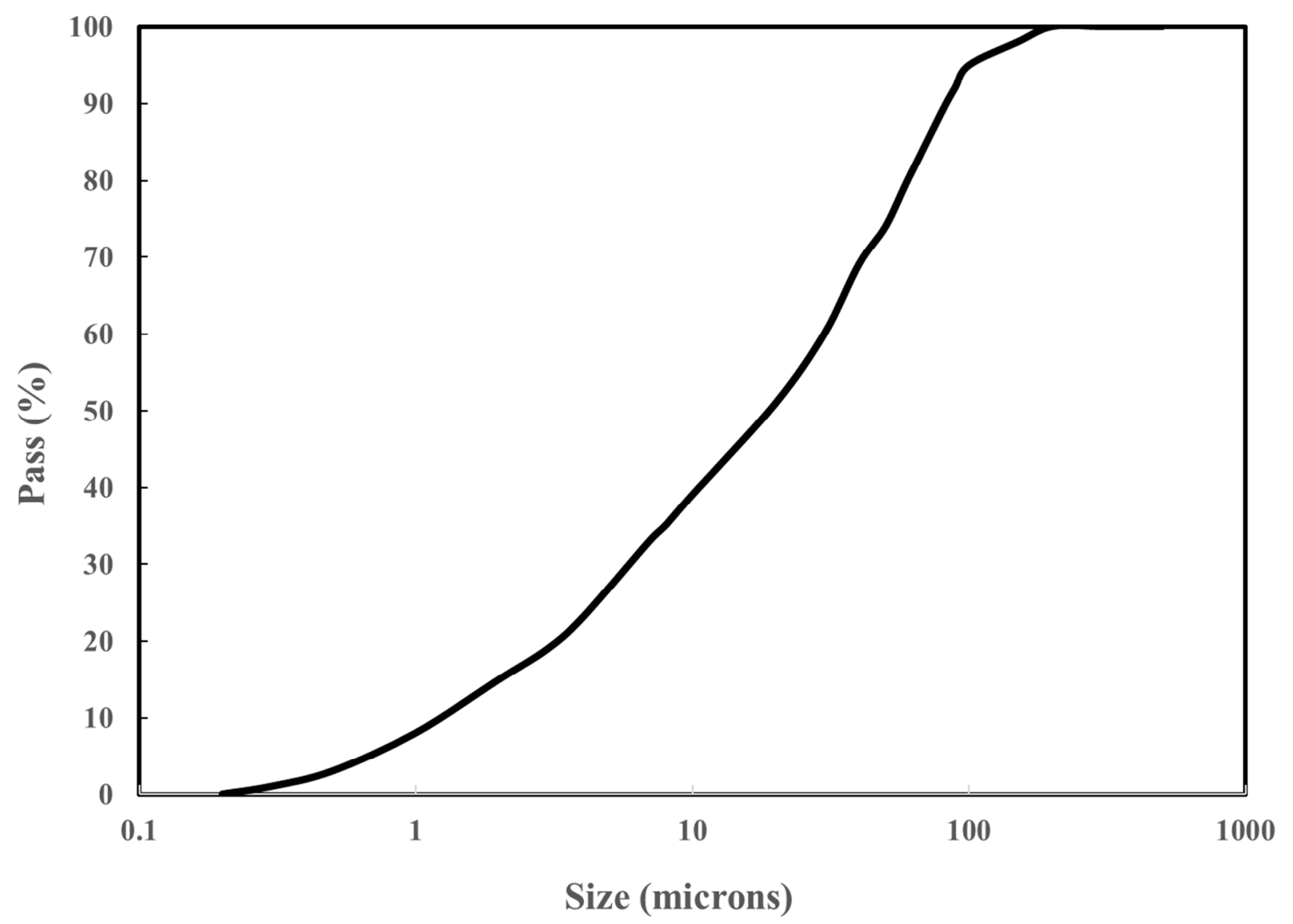

Fig.2: Particle size analysis of ground steel slag 


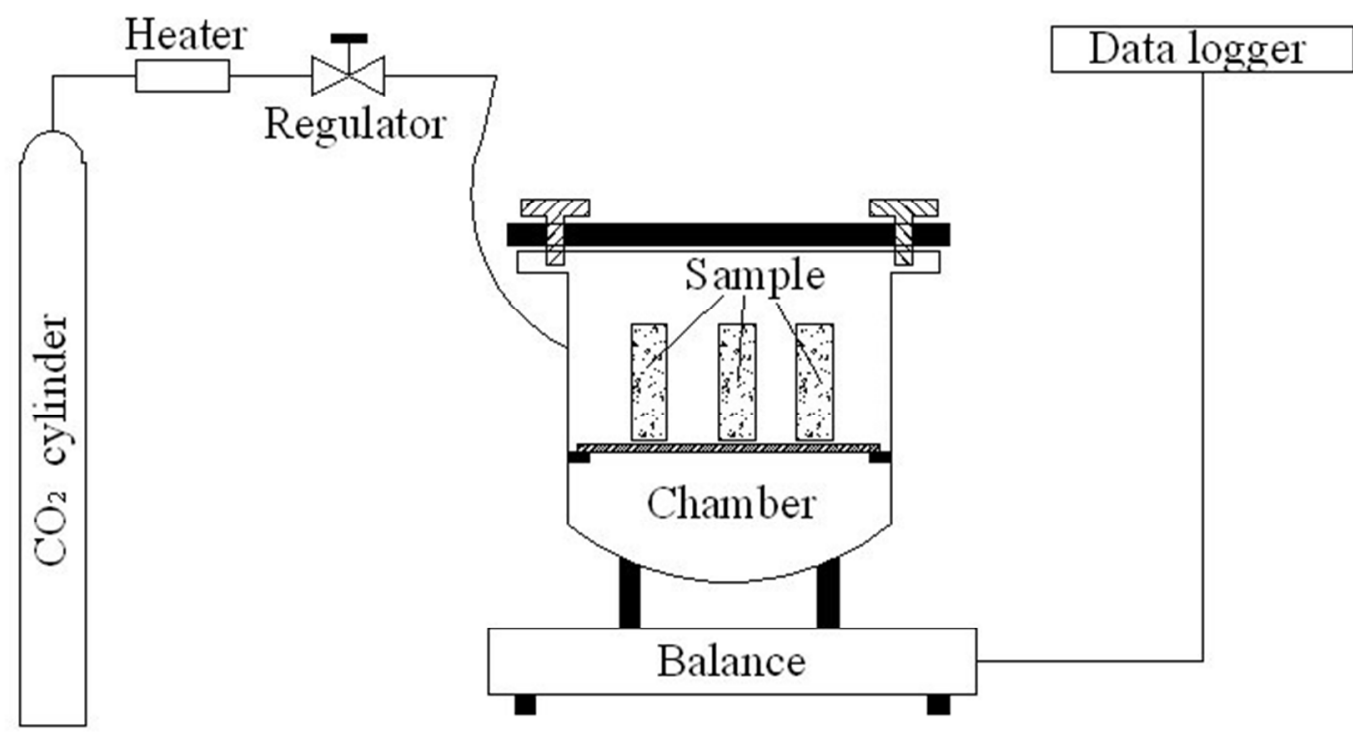

Fig. 3: Carbonation setup for steel slag paste samples 


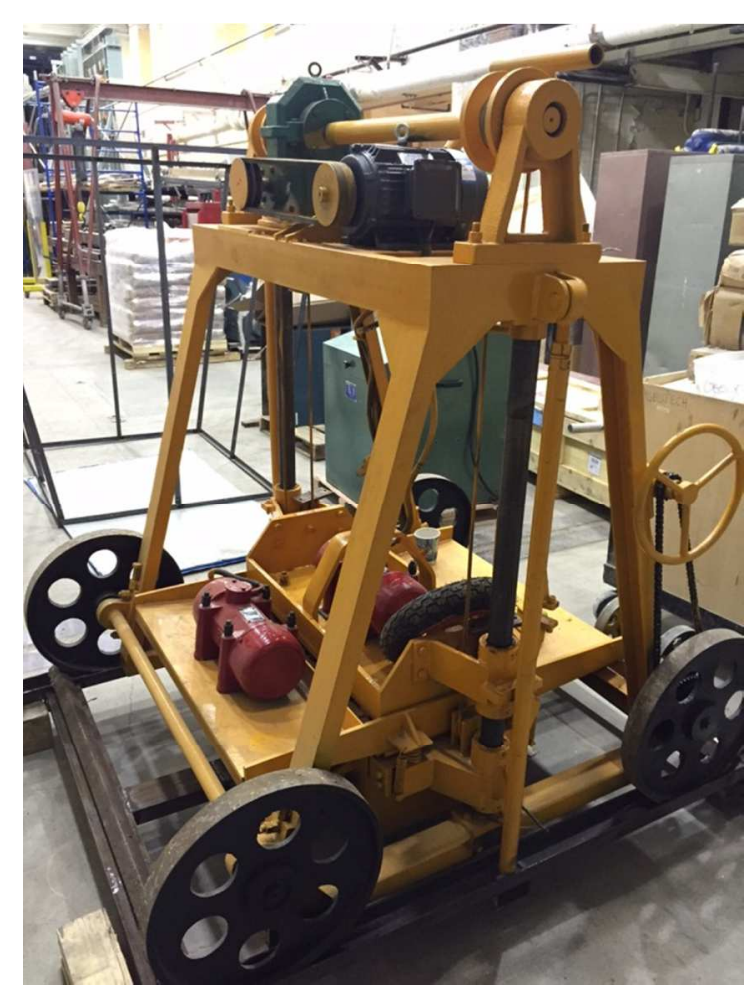

Fig. 4: Industrial block machine used in the pilot production 


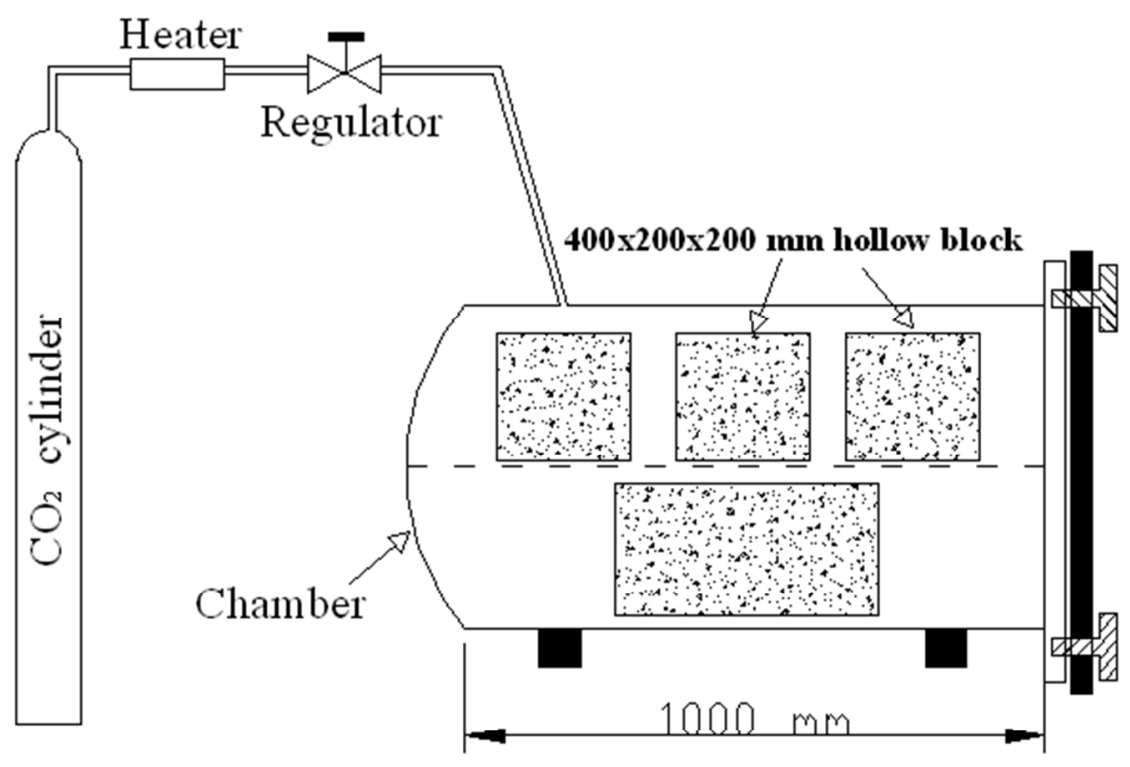

Fig. 5: Carbonation curing setup for steel slag masonry blocks 


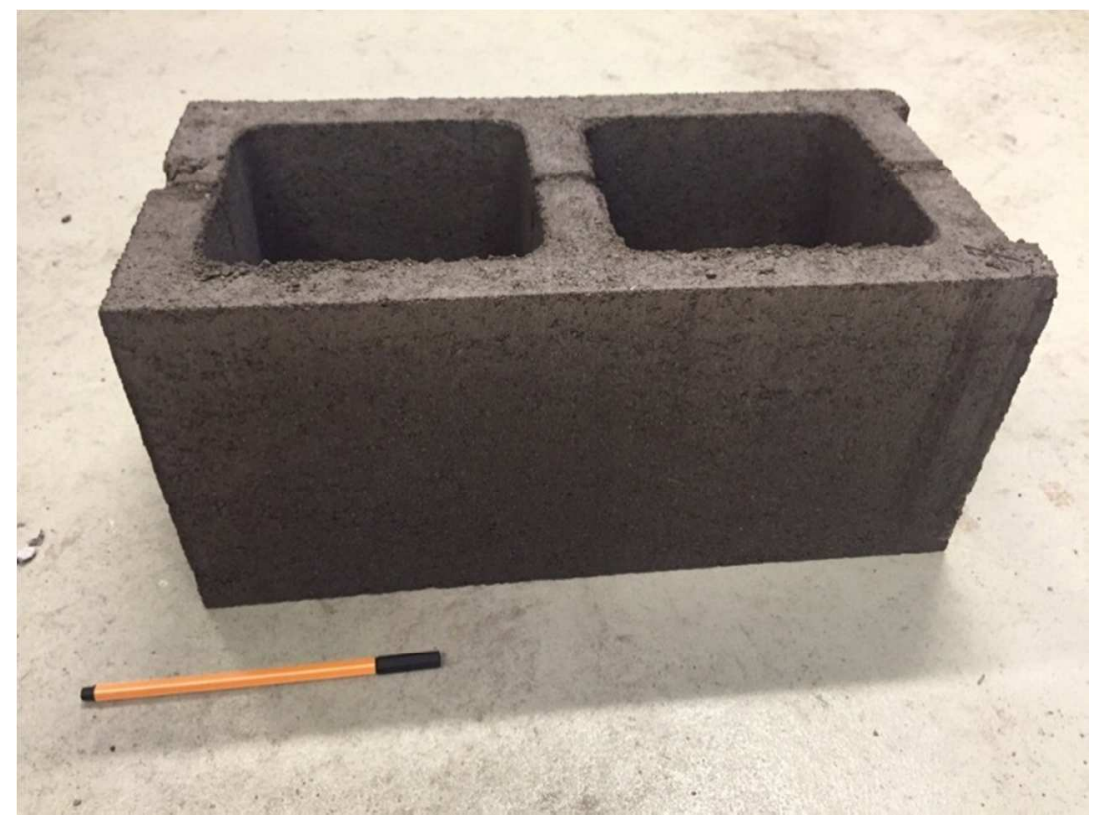

Fig. 6: Full-size steel slag masonry blocks 


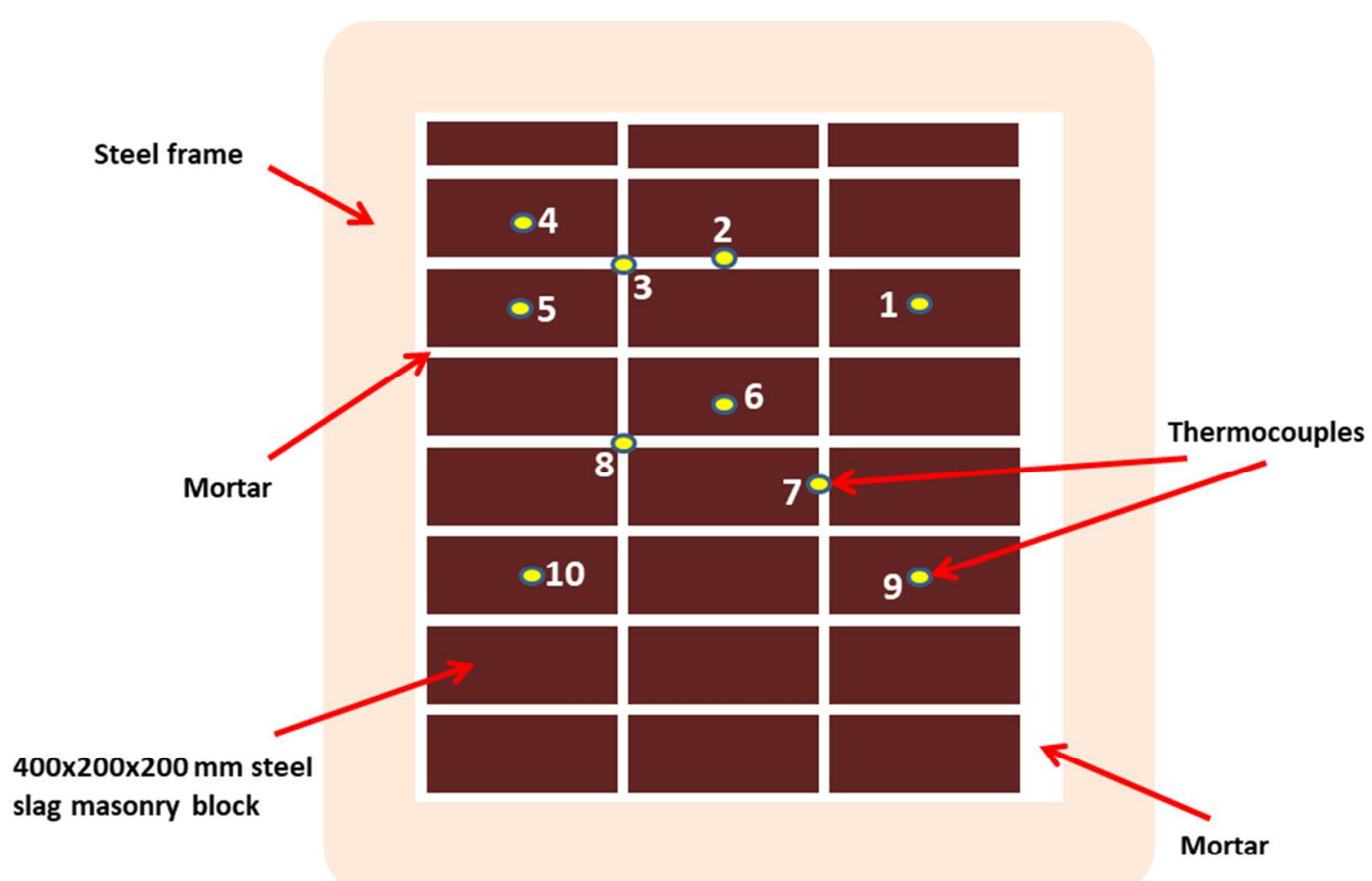

Fig. 7: Locations of installed thermocouples on the unexposed face of the wall 


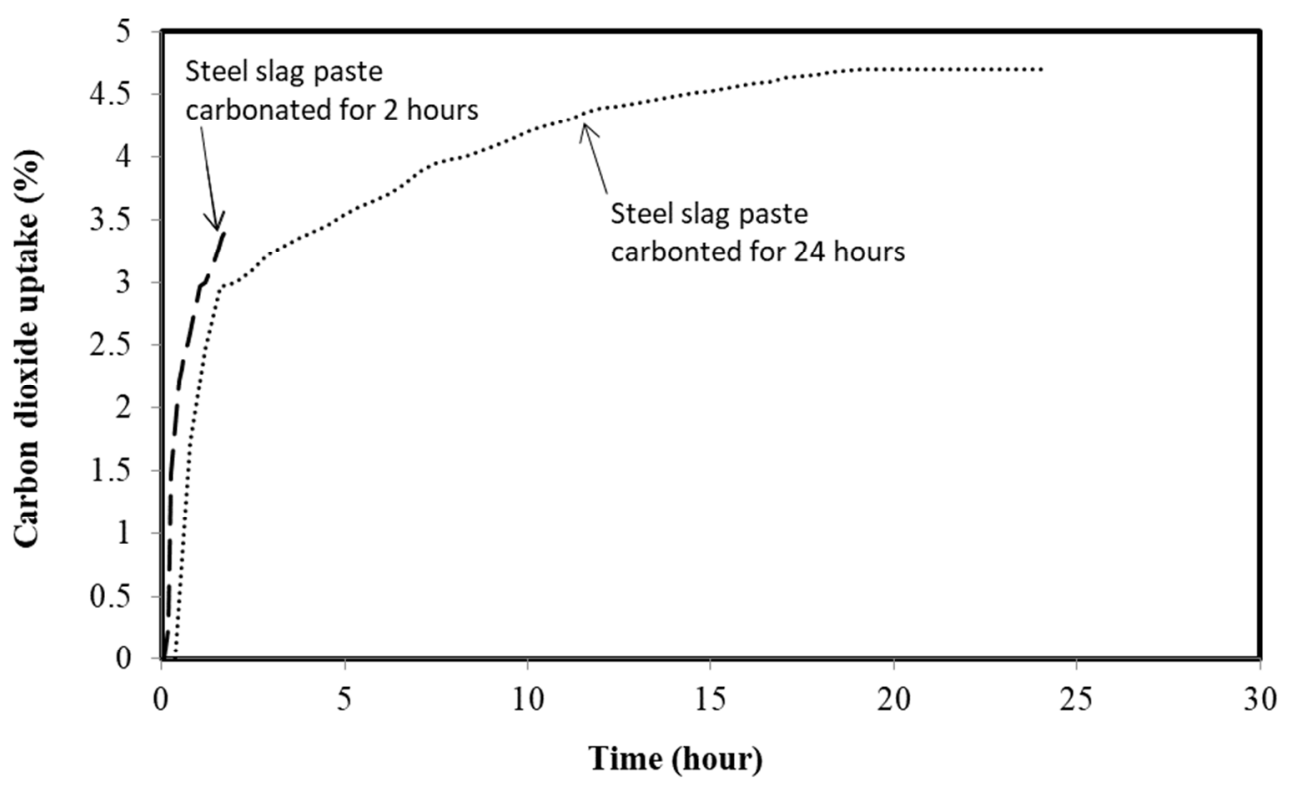

Fig. 8: Mass curves for carbonated steel slag 


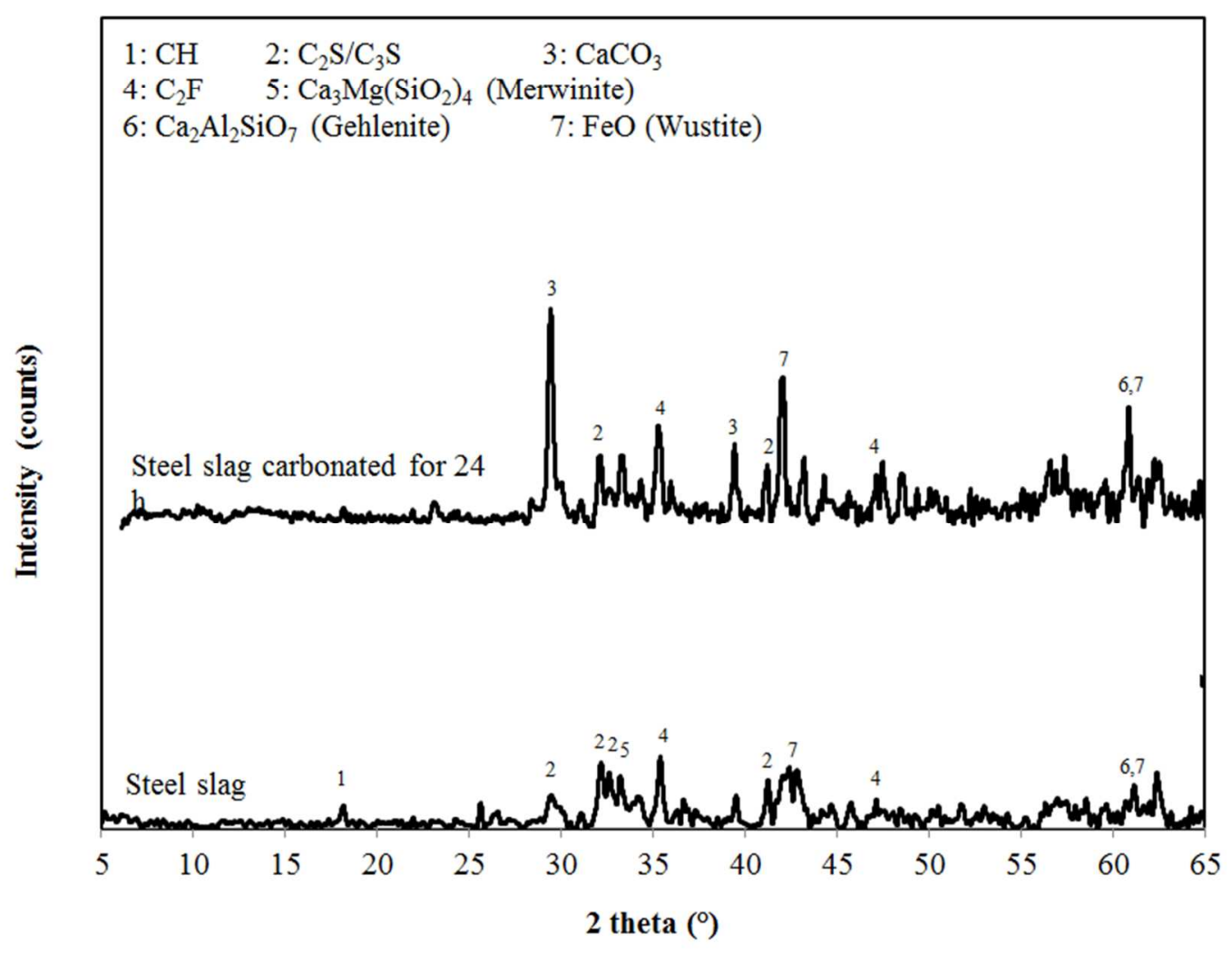

Fig. 9: XRD patterns of steel slag and carbonated steel slag 


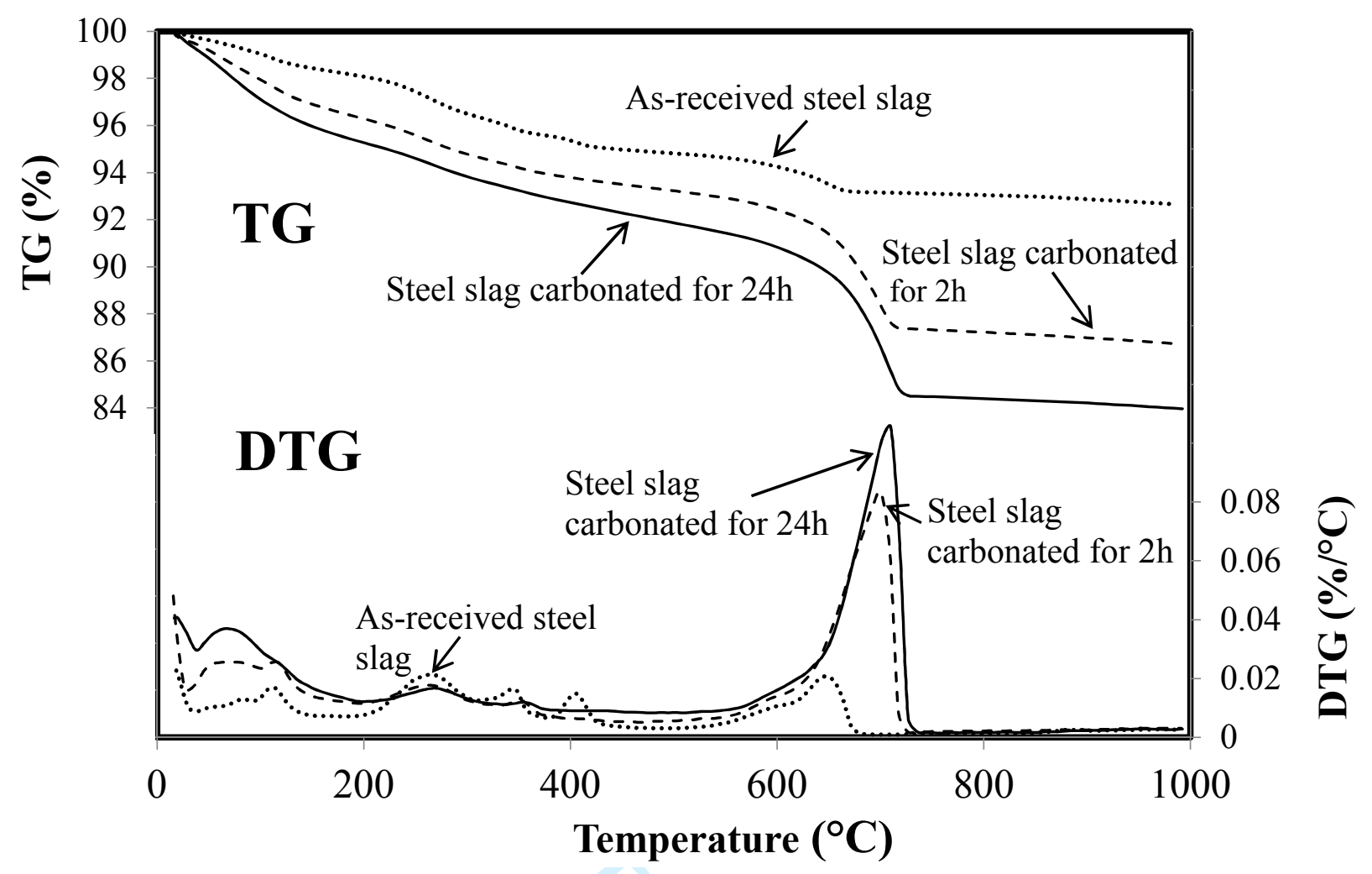

Fig. 10: TG/DTG curves for the carbonated and as-received slag 


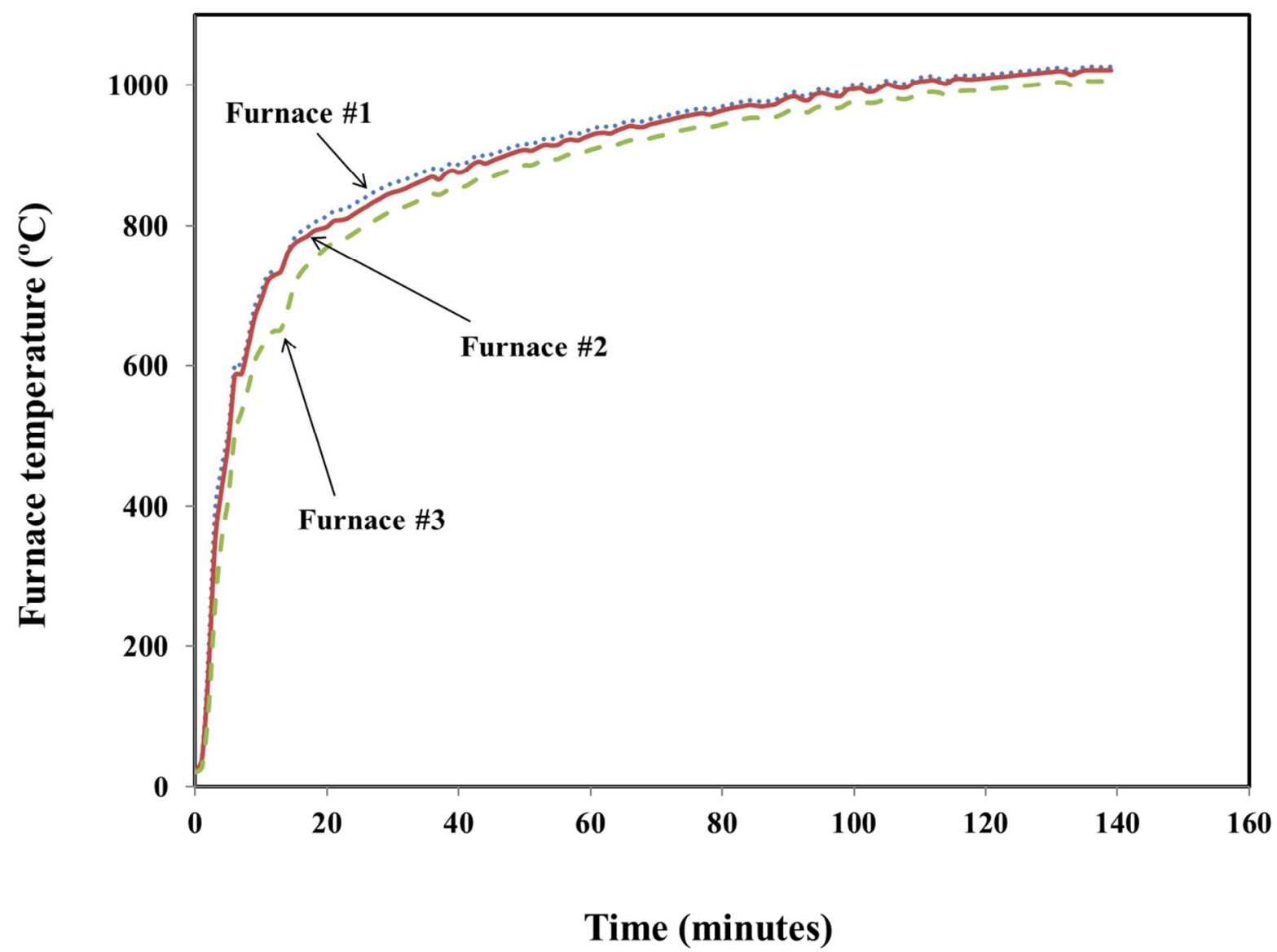

Fig. 11: Temperature curves of exposed face 


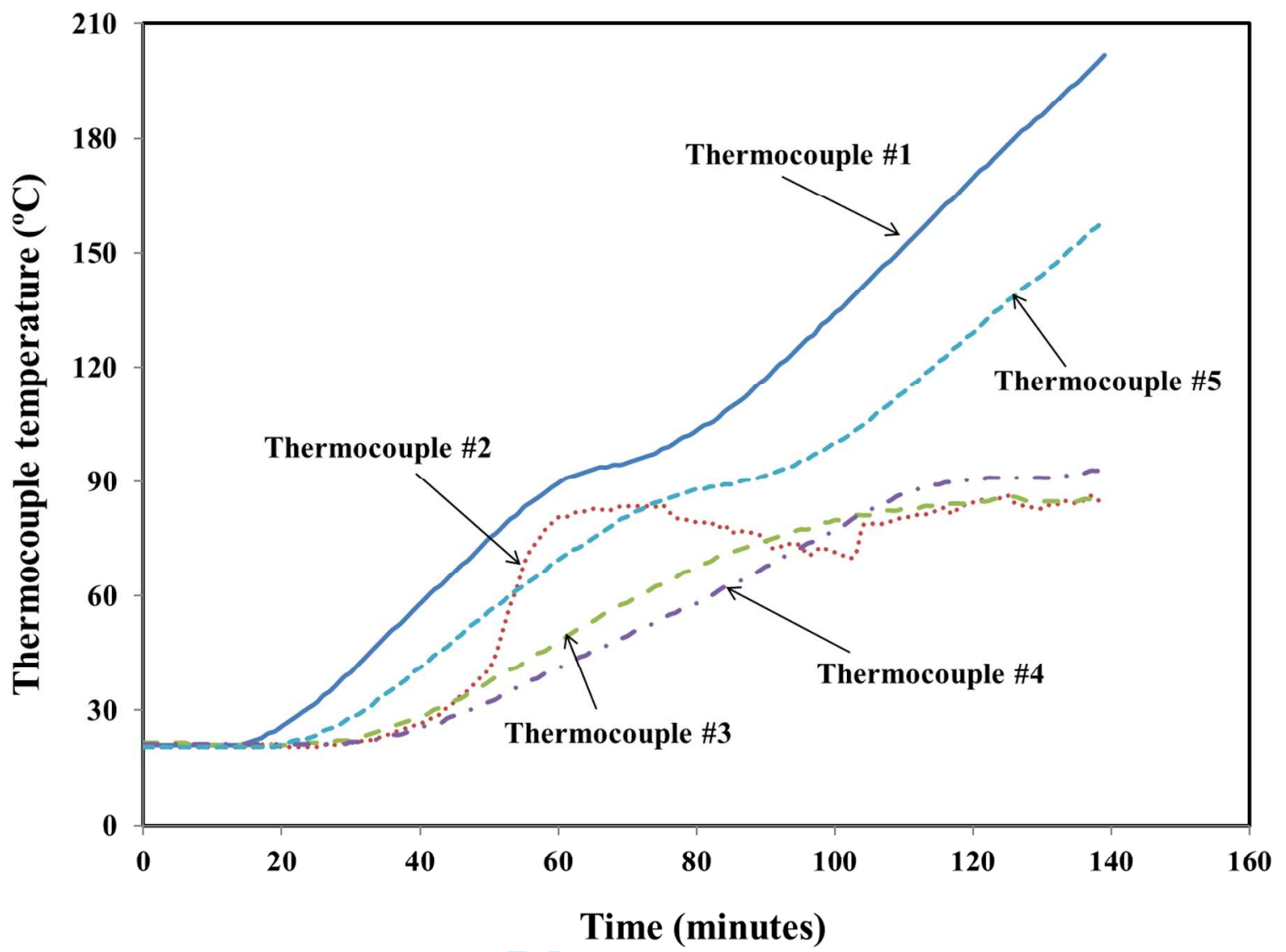

a)

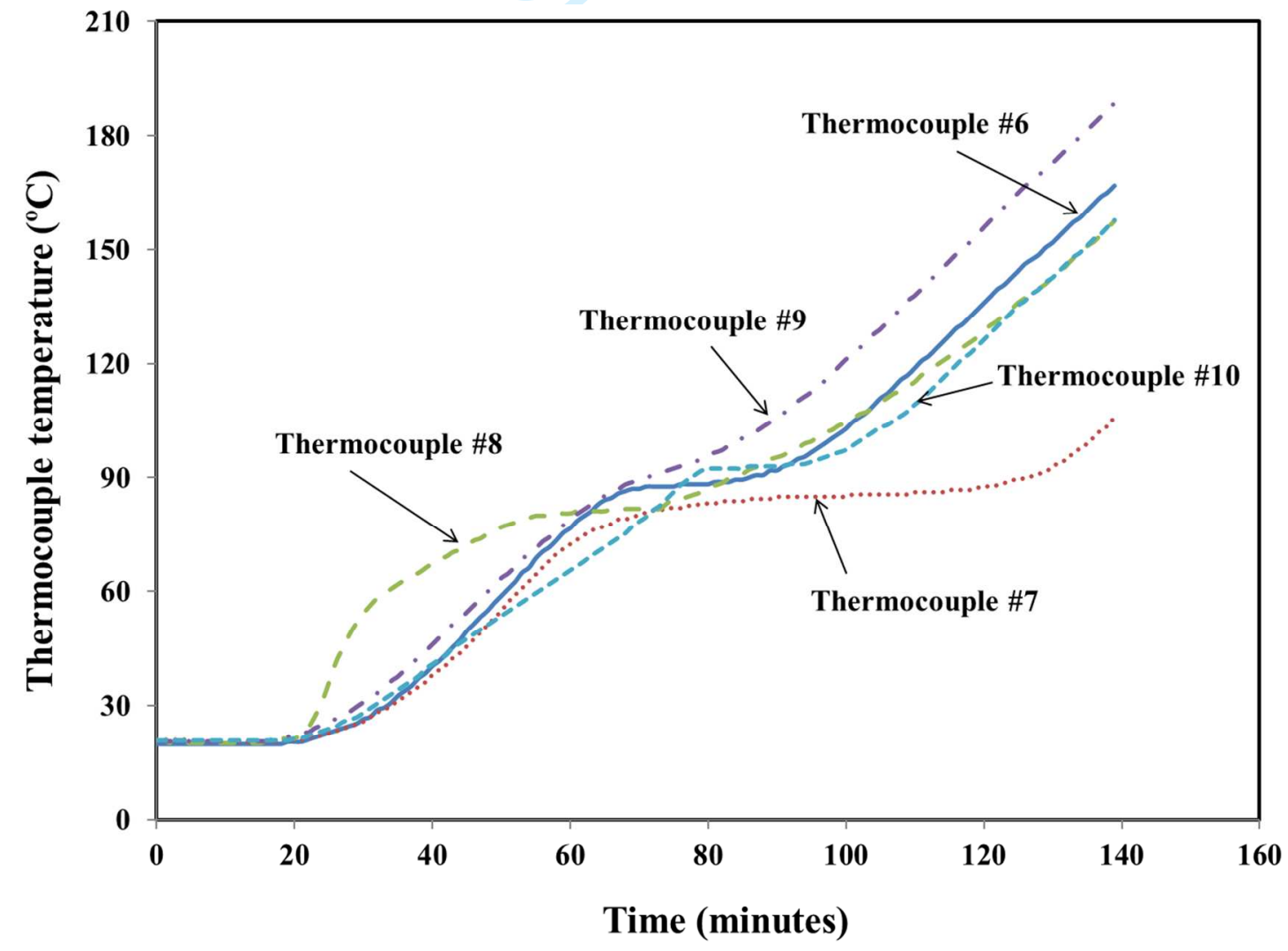

b)

Fig. 12: Temperature curves of a) thermocouples 1-5 and b) thermocouples 6-10 


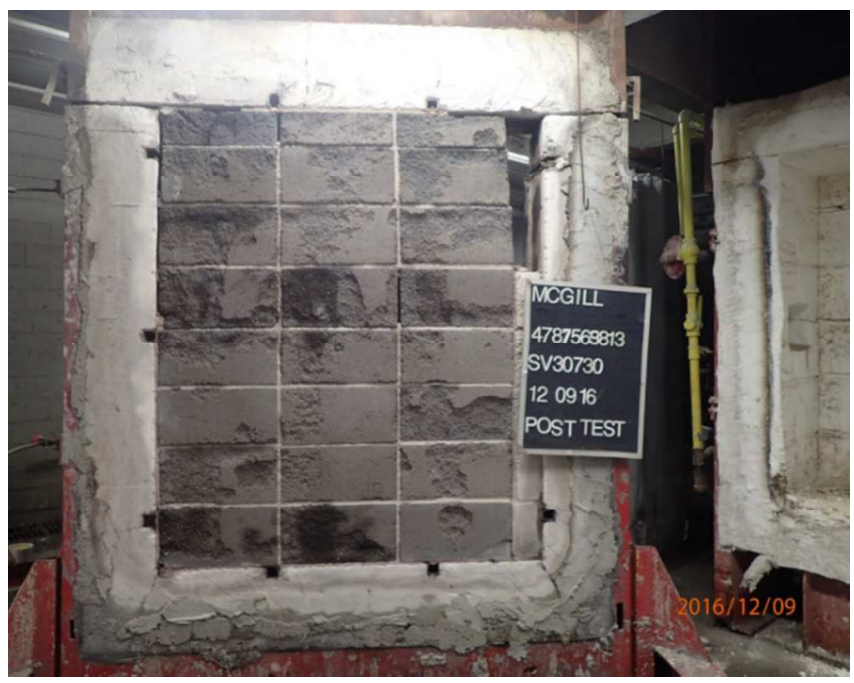

a) Exposed face of the wall

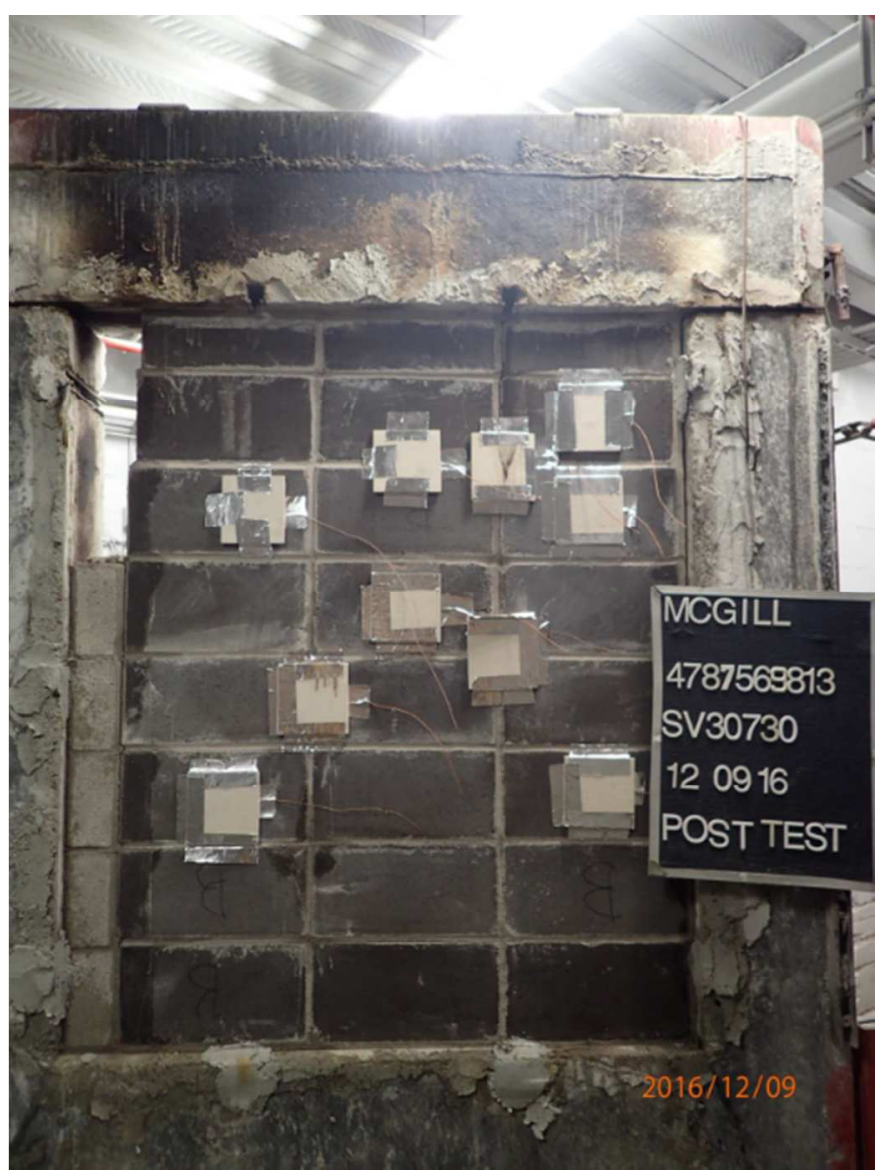

b) Unexposed face of the wall

Fig. 13: After fire test: a) Exposed and b) unexposed side at the end of the test 
Table 1: Chemical composition of steel slag

\begin{tabular}{lllllllllll}
\hline & $\mathrm{SiO}_{2}$ & $\mathrm{TiO}_{2}$ & $\mathrm{Al}_{2} \mathrm{O}_{3}$ & $\mathrm{Fe}_{2} \mathrm{O}_{3}$ & $\mathrm{MnO}$ & $\mathrm{MgO}$ & $\mathrm{CaO}$ & $\mathrm{Na}_{2} \mathrm{O}$ & $\mathrm{K}_{2} \mathrm{O}$ & $\mathrm{P}_{2} \mathrm{O}_{5}$ \\
\hline Steel slag (\%) & 12.47 & 0.87 & 6.87 & 19.48 & 3.84 & 10.57 & 39.08 & $<0.01$ & 0.01 & 0.41 \\
\hline
\end{tabular}

Table 2: Mixture proportion of steel slag masonry blocks

\begin{tabular}{ccccc}
\hline Product & $\begin{array}{c}\text { Steel slag } \\
\left(\mathrm{kg} / \mathrm{m}^{3}\right)\end{array}$ & $\begin{array}{c}\text { Granite } \\
\text { aggregate } \\
\left(\mathrm{kg} / \mathrm{m}^{3}\right)\end{array}$ & Water/slag ratio & Formation \\
\hline $\begin{array}{c}\text { Steel slag masonry } \\
\text { blocks }\end{array}$ & 770 & 1320 & 0.2 & Block machine \\
\hline
\end{tabular}

Table 3: Carbon dioxide uptake of steel slag paste

Id

Carbonation time

(hours)
Mass gain

$(\%)$
Mass curve (\%)

\begin{tabular}{lccc} 
& & $(\%)$ & \\
& & & \\
\hline Steel slag paste 2 & 2 & $3.3 \pm 0.07$ & 3.5 \\
\hline Steel slag paste 24 & 24 & $4.8 \pm 0.25$ & 4.7 \\
\hline
\end{tabular}

Table 4: Compressive strength of carbonated steel slag paste

\begin{tabular}{cccc}
\hline Id & $\begin{array}{c}\text { Carbonation time } \\
\text { (hours) }\end{array}$ & $\begin{array}{c}\text { Age at test } \\
\text { (days) }\end{array}$ & $\begin{array}{c}\text { Compressive strength } \\
\text { (MPa) }\end{array}$ \\
\hline SS-C2-0 & 2 & 2 hours & $13.4 \pm 2.8$ \\
\hline SS-C24-0 & 24 & 24 hours & $24.3 \pm 4.1$ \\
\hline SS-C2-35 & 2 & 35 & $23.3 \pm 6.6$ \\
\hline SS-C24-35 & 24 & 35 & $35.9 \pm 11.9$ \\
\hline
\end{tabular}


Table 5: Water and $\mathrm{CO}_{2}$ loss obtained by $\mathrm{TG}$

\begin{tabular}{ccccc}
\hline Sample & $\begin{array}{c}\text { Carbonation } \\
\text { (hours) }\end{array}$ & $\begin{array}{c}\text { Water loss in } \\
\text { calcium-based } \\
\text { hydrates }(\%)\end{array}$ & $\begin{array}{c}\mathrm{CO}_{2} \text { loss } \\
\text { in } \mathrm{CaCO}_{3} \\
(\%)\end{array}$ & $\begin{array}{c}\mathrm{CaCO}_{3} \\
(\%)\end{array}$ \\
\hline As-received steel slag & - & 2.6 & 1.8 & 3.8 \\
\hline Carbonated steel slag & 24 & 5.6 & 7.1 & 16.2 \\
\hline
\end{tabular}

Table 6: Leaching behavior of carbonated steel slag

\begin{tabular}{|c|c|c|c|}
\hline & $\begin{array}{c}\text { Carbonated steel slag } \\
\text { paste }[\text { slag+water] }(\mathrm{mg} / \mathrm{l})\end{array}$ & $\begin{array}{l}\text { Fresh steel slag [not } \\
\text { carbonated] }(\mathrm{mg} / \mathrm{l})^{* *}\end{array}$ & $\begin{array}{l}\text { Limit according to } \\
\text { EPA (mg/l) }\end{array}$ \\
\hline Arsenic & *ND & 0.002 & 5.0 \\
\hline Barium & 1.9 & 0.41 & 100.0 \\
\hline Cadmium & ND & 0.001 & 1.0 \\
\hline Chromium & 0.62 & 0.01 & 5.0 \\
\hline Lead & ND & 0.004 & 5.0 \\
\hline Selenium & 0.36 & ND & 1.0 \\
\hline Silver & 0.13 & 0.0064 & 5.0 \\
\hline Mercury & ND & 0.0003 & 0.2 \\
\hline Zinc & 1.7 & 0.07 & 250.0 \\
\hline Vanadium & 0.77 & - & 24.0 \\
\hline Molybdenum & ND & - & 350.0 \\
\hline Nickle & ND & 0.012 & 20.0 \\
\hline
\end{tabular}

*ND: Not Detected

**Proctor et al. (2000) 
Table 7: Carbon uptake of steel slag masonry block

\begin{tabular}{ccccc}
\hline Product & $\begin{array}{c}\text { Preconditioning } \\
\text { (hours) }\end{array}$ & $\begin{array}{c}\mathrm{CO}_{2} \text { pressure } \\
(\mathrm{MPa})\end{array}$ & $\begin{array}{c}\mathrm{CO}_{2} \text { exposure } \\
\text { (hours) }\end{array}$ & $\begin{array}{c}\text { Carbon } \\
\text { dioxide } \\
\text { uptake (\%) }\end{array}$ \\
\hline $\begin{array}{c}\text { Steel slag } \\
\text { masonry } \\
\text { block }\end{array}$ & 4 & 0.4 & 24 & $10.7 \pm 0.7$ \\
\hline
\end{tabular}

Table 8: Water absorption and moisture content of steel slag and cement masonry block

\begin{tabular}{ccc}
\hline ID & Water absorption (\%) & Moisture content (\%) \\
\hline Cement masonry block & $5.5 \pm 0.2$ & 1.7 \\
\hline Steel slag masonry block & $6.9 \pm 0.8$ & $1.5 \pm 0.1$ \\
\hline
\end{tabular}

Table 9: Compressive strength and density of steel slag masonry block

\begin{tabular}{cccccc|cc}
\hline ID & $\begin{array}{c}\text { Dimension } \\
(\mathrm{mmxmm \times mm})\end{array}$ & $\begin{array}{c}\text { Mass } \\
(\mathrm{kg})\end{array}$ & $\begin{array}{c}\text { Net } \\
\text { area } \\
\left(\mathrm{mm}^{2}\right)\end{array}$ & $\begin{array}{c}\text { Percent } \\
\text { solid } \\
(\%)\end{array}$ & $\begin{array}{c}\text { Load } \\
(\mathrm{kN})\end{array}$ & $\begin{array}{c}\text { Density } \\
\left(\mathrm{kg} / \mathrm{m}^{3}\right)\end{array}$ & $\begin{array}{c}\text { Compressive } \\
\text { strength } \\
(\mathrm{MPa})\end{array}$ \\
\hline $\mathrm{D}$ & $401 \times 197 \times 195$ & 20.9 & 47082 & 59.6 & 1096.9 & 2276.4 & 23.3 \\
\hline $\mathrm{E}$ & $399 \times 198 \times 194$ & 20.7 & 47932 & 60.7 & 1116.7 & 2226.1 & 23.3 \\
\hline F & $399 \times 198 \times 187$ & 20.0 & 48280 & 61.1 & 1048.2 & 2215.3 & 21.7 \\
\hline G & $400 \times 198 \times 198$ & 21.1 & 47221 & 59.6 & 1129.1 & 2256.7 & 23.9 \\
\hline Average & - & 20.7 & 47628 & 60.3 & 1097.7 & 2243.6 & 23.1 \\
\hline Standard deviation & - & 0.4 & 495 & 0.7 & - & 18.4 & 0.8 \\
\hline
\end{tabular}


Table 10: Cost and utilization of slag masonry block

\begin{tabular}{|c|c|c|c|c|c|}
\hline & $\begin{array}{l}\text { Annual CO2 } \\
\text { sequestration }\end{array}$ & $\begin{array}{l}\text { Annual } \\
\text { cement } \\
\text { elimination }\end{array}$ & $\begin{array}{l}\text { Annual total } \\
\text { avoidance of } \mathrm{CO} 2 \\
\text { into the atmosphere }\end{array}$ & $\begin{array}{c}\text { Binder cost for } \\
\text { the cement-based } \\
\text { block }\end{array}$ & $\begin{array}{l}\text { Binder cost for } \\
\text { the slag } \\
\text { masonry block }\end{array}$ \\
\hline Value & 1.5 million tonnes & $\begin{array}{c}3.6 \text { million } \\
\text { tonnes }\end{array}$ & 4.4 million tonnes & $\$ 0.21$ per unit & $\$ 0.08$ per unit \\
\hline
\end{tabular}

